\title{
Effects of Phenylbutazone and Indomethacin on the Post-operative Course following Experimental Orthopaedic Surgery in Dogs
}

\author{
By Susan W. Mbugua, Lasse A Skoglund and Per Løkken.
}

Department of Public Health, Pharmacology and Toxıcology and Department of Clinical Studies, Faculty of Veterinary Medicine, College of Agnculture and Veterınary Sciences, University of Nairobi, Kenya, and Department of Pharmacology and Toxicology, Norwegian College of Veterınary Medicine, Oslo, Norway.

\begin{abstract}
Mbugua, S. W., L. A. Skoglund and P. Lokken: Effects of phenylbutazone and indomethacin on the post-operative course following experimental orthopaedic surgery in dogs. Acta vet. scand. 1989, 30, 27-35. - Randomized placebo-controlled crossover studies were carried out in dogs to evaluate how two non-steroidal antiinflammatory drugs (NSAID) might modulate an acute post-traumatic inflammatory reaction. Two "identical" surgical interventions were performed on the forelımbs of each anımal with an interval of 28 days, to enable a paired comparison of the inflammatory signs and the wound/bone healing processes. At one operation 8 dogs received $300 \mathrm{mg}$ phenylbutazone twice daily for 8 days starting on the day before surgery, and at the other operation matching placebo tablets were given. In a similar placebo-controlled trial another group of 8 dogs received $5 \mathrm{mg}$ indomethacin twice dally. With phenylbutazone the post-operative swelling was not significantly reduced compared to placebo, but there was less pain and limping. With indomethacin the swelling was somewhat reduced, but there was no consistent difference to placebo in the pain and limping assessments. None of the drugs appeared to distınctly effect the wound or fracture healing, as evaluated by clinical inspection, comparison of radiographs and comparison of bone sections from the sites of surgery. It proved difficult to select an appropriate dosage of indomethacin due to its high potential to induce GI ulceration and bleeding in dogs.

In this experimental surgical model with an acute inflammation, neither phenylbutazone nor indomethacin showed impressive ant1-inflammatory or analgesic properties. In the same model paracetamol has proved to significantly and more efficiently, reduce both swelling and pain without any noticeable adverse effects, and appears to be a better alternative than the two presently tested NSAID.
\end{abstract}

antı-1nflammatory effects; swelling; pain; wound/bone healıng.

\section{Introduction}

With phenylbutazone and indomethacin as forerunners, a host of new non-steroidal anti-inflammatory drugs (NSAID) has been introduced during the past 20 years. They belong to many chemical classes, but have similar or identical modes of action related to their ability to interfere with the forma- tion of mediators of inflammation, such as the prostaglandins. The prototype is acetylsalicylic acid, hence they are often referred to as "aspirin-like" drugs. With some variation they share anti-inflammatory, analgesic and antipyretic properties, as well as side effects such as gastrointestinal irritation and bleeding. 
NSAID are widely used in veterinary practice, although not as frequently as in human medicine. They are, as stated by Higgins (1985), prescribed for conditions as clinically diverse as equine exertional myopathy ("azoturia"), spasmodic colic, arthroses and arthritic conditions, tendonitis, and as postoperative prophylaxis to control untoward inflammatory sequelae.

The anti-inflammatory drugs used in human surgery and traumatology seem mostly to have been selected according to their performance in patients with rheumatoid arthritis (Løkken \& Skjelbred 1981), and essentially the same drugs have been adopted for use in veterinary surgery. Rheumatoid inflammation, however, differs markedly from an acute post-traumatic inflammation, and anti-inflammatory drug effects are not necessarily the same in these different conditions.

There is a lack of reliable models for clinical assessment of anti-inflammatory effects, which is unfortunate since recent research has showed clearly the wide gap between our concepts garnered mainly from in vitro studies and the almost complete lack of data indicating that the results obtained in vitro are meaningful in vivo (Vinegar \& Truax 1982).

A well controlled model for evaluation of drug effects in human surgery, is based on bilateral oral surgery. Studies in this model revealed that drugs which efficiently reduce rheumatoid swelling, e.g. acetylsalicylic acid, oxyphenbutazone and ibuprofen, had a little or no effect on the post-operative swelling, while paracetamol which often is said to be without anti-inflammatory activity, reduced the swelling by about $30 \%$ (Lokken et al. 1975, Album et al. 1977, Løkken \& Skjelbred 1980, Skjelbred 1984). Glucocorticoids reduced the swelling by about $50 \%$ and gave in addition a striking pain relief
(Skjelbred \& Løkken 1982a, b). Conclusions from oral surgery, however, may not necessarily apply to surgery and traumata in other parts of the body, e. g. the extremities, in connection with which NSAID are frequently prescribed.

An experimental model with bilateral orthopaedic surgery on the forelimbs of dogs has recently been established to allow placebocontrolled studies on how steroidal and non-steroidal anti-inflammatory drugs might modulate the signs of an acute post-traumatic inflammatory reaction and the healing process (Mbugua et al. 1988). For the present trials phenylbutazone and indomethacin were selected to be tested in this model. Phenylbutazone is probably still the most widely used NSAID in veterinary practice Lees \& Higgins 1985). Indomethacin is another NSAID which has been commonly used in humans, but only infrequently in veterinary medicine. A main reason for including indomethacin was that it has been reported to delay or inhibit fracture healing in experimental models using rats (Sudmann et al. 1979, Elves et al. 1982).

\section{Materials and methods}

\section{Experimental design}

The trials were carried out as randomized, placebo-controlled crossover studies in which two "identical" surgical soft tissue/ bone interventions were performed on the forelimbs of each animal with an interval of 28 days to allow paired comparison of the post-operative courses.

\section{Animals}

Mongrel dogs of either sex, weighing from 12 to $21 \mathrm{~kg}$, were used. They were all dewormed, but had no other verifiable diseases. The ethical aspects of the study were approved and supervised by the relevant authority at the Faculty of Veterinary Medicine, University of Nairobi. 


\section{Drugs}

Phenylbutazone: For one operation 8 dogs received orally $300 \mathrm{mg}$ phenylbutazone (Mac's Pharmaceuticals, Nairobi, Kenya) twice daily. Medication started the day before surgery and lasted for 8 days. Placebo medication was given at the other operation. The treatments were allocated according to a randomization list, so that half of the dogs received the active drug at the 1 st operation. To keep the trials blind to the surgeon, the drugs were administered by an assistant who had no other responsibilities in the trial.

Indomethacin: Our plan was to administer to another group of $8 \mathrm{dogs}, 25 \mathrm{mg}$ indomethacin (Indocid ${ }^{\mathbb{B}}$, Merck-Sharp \& Dohme, N. Y., USA) twice daily for 8 days, in a similar placebo-controlled manner. This medication, however, had to be discontinued on the 1st post-operative day because of signs of toxicity. A third group of 8 dogs was then included which received $5 \mathrm{mg}$ indomethacin (Confortid ${ }^{\circledR}$, Dumex, Copenhagen, Denmark) twice daily administered in a similar way as phenylbutazone.

\section{Surgical procedure}

The operations were carried out under general thiopentone/halothane anaesthesia after premedication with acetylpromazine and atropine, as described by Mbugua et al. (1988). The surgical procedure involved transsection of the 3rd metacarpus with an oscillating saw and thereafter stabilization with a 6 hole mini Dynamic Compression Plate.

\section{Assessments}

A device designed for foot/limb volumetry (Mbugua et al. 1988) was used to measure the swelling of the limb. The limb was immersed into a cylinder filled with water, until a mark on the shaved skin of the limb reached the top of the cylinder. This was done pre- and post-operatively and the difference in volume of displaced water recorded. The average of 3 successive measurements was used to represent the volume of the dogs' limb.

Pain was estimated by the surgeon who exerted digital pressure on the site of surgery and marked on a visual analogue scale (VAS) that ran from "no pain" $(0 \mathrm{~mm})$ to "pain cannot be worse" (100 mm). Limping was marked on a $100 \mathrm{~mm}$ VAS from "no limping" to "limping cannot be worse". These assessments were made between 8 and 9 a. m. every day for a week after each operation and then on days 10,14 and 21 after surgery. At the same time any abnormalities in wound healing as well as any other noticeable clinical signs were recorded.

Bone healing was monitored according to Mbugua et al. (1988) by comparison of radiographs taken 2, 4, 6 and 8 weeks after the two operations for bone union, callus formation, signs of infection and foreign body acceptance. The bone healing was also assessed by comparing bone sections from the sites of surgery obtained when the dogs were euthanized 8 weeks after the 2 nd operation. The sections were cut in a cryo-microtome before staining and comparative assessment.

\section{Statıstical analyses}

Statistical analyses of the assessments of swelling, pain and limping were performed with a two-sided Wilcoxon signed rank test with corrections for ties (Lehman \& d'Abre$r a$ 1975). A significance level of $5 \%$ was used.

\section{Results}

Phenylbutazone

Swelling

Phenylbutazone did not reduce the postoperative swelling significantly compared to placebo (Table 1). 


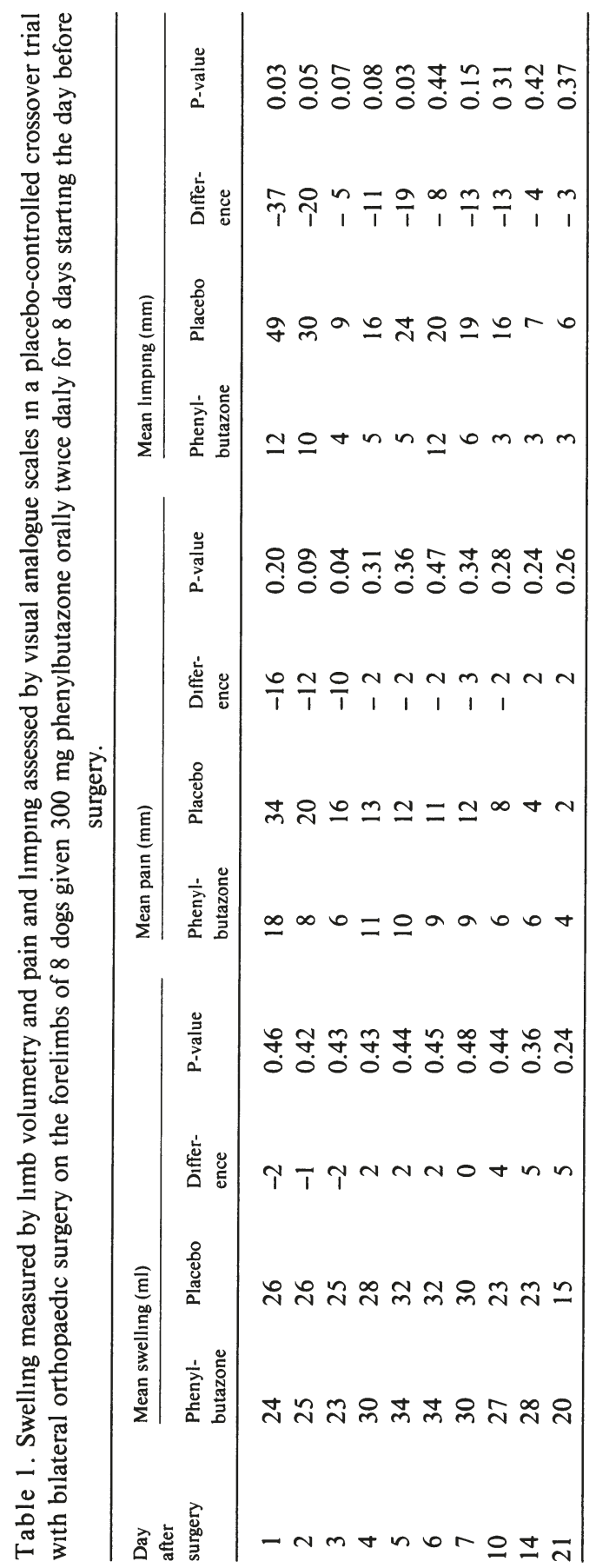

\section{Pain and limping}

Less pain was assessed during the first days after the operation when phenylbutazone was administered (Table 1). The difference was significant on Day 3. There was also less limping after the operation when phenylbutazone was given (Table 1). The differences were significant on Days 1, 2 and 5.

\section{Toxicity/adverse effects}

No clinical signs of gastrointestinal toxicity or other potential adverse drug reactions were observed.

\section{Wound and bone healing}

Clinically there appeared to be a tendency towards slightly better wound healing after the operation when placebo was given. Comparison of the two sets of radiographs taken 4 and 6 weeks after surgery also revealed tendencies in favour of placebo, both with regard to bone union, callus formation and the tissue acceptance of the plates and screws. After 8 weeks, however, there were no noticeable differences. Comparison of the bone sections after the two operations revealed no clear-cut difference in the healing process.

\section{Indomethacin (25 $\mathrm{mg}$ twice dally)}

The medication was discontinued on day 1 post-operatively, since signs of toxicity were observed in all dogs, e. g. lethargy, vomiting and bloody stool. They had then received a total dose of $125 \mathrm{mg}$ indomethacin. One dog died on Day 5 post-operatively. Autopsy revealed intestinal ulcers in all dogs that had been given this dosage of indomethacin.

\section{Indomethacin (5 mg twice daily)}

\section{Swelling}

There was a tendency towards less swelling after the operation when indomethacin was administered. The differences were significant on Days 7, 10 and 14 (Table 2). 


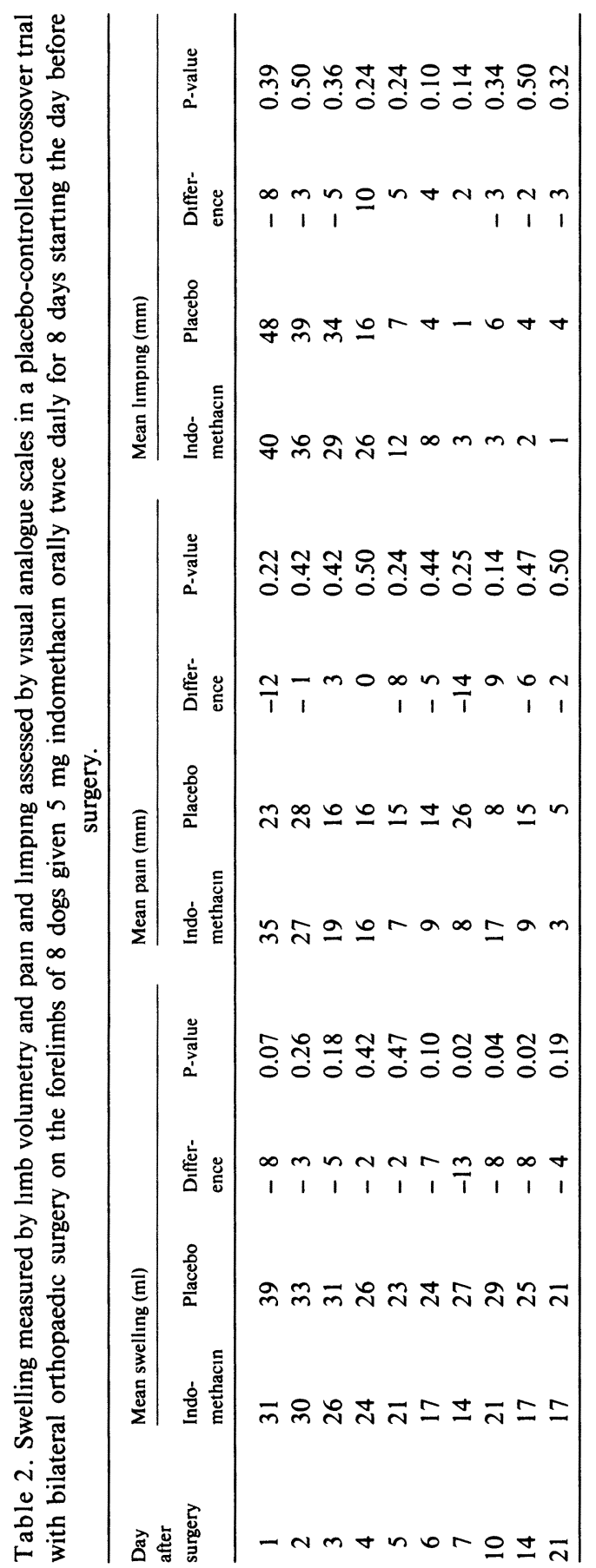

\section{Pain and limping}

There appeared to be no consistent difference between the pain assessments after the two operations (Table 2). There was no significant difference in the limping after the two operations (Table 2).

\section{Toxictty/adverse effects}

One of the dogs developed bloody stool on Day 5 post-operatively. Otherwise there were no evident clinical signs of toxicity. All dogs, however, showed healing intestinal ulcers at autopsy.

\section{Wound and bone healing}

No noticeable differences were observed in the wound and bone healing, either by the clinical examination or when the two sets of radiographs and bone sections after the two operations were compared.

\section{Discussion}

Many traumatic painful swellings have been treated with phenylbutazone. Results reported from clinical trials range from excellent to no effect, most of them based on subjective impression. The present controlled experiment in dogs did not reveal any phenylbutazone-induced reduction of post-operative swelling, although the drug gave significant pain relief. Our findings agree with some studies in humans based on objective measurements of swelling, according to which phenylbutazone and its bioactive metabolite oxyphenbutazone have little or no capacity of reducing an acute post-traumatic swelling (Olesen \& Zachariae 1965, Goldie et al. 1974, Album et al. 1977).

With indomethacin there was a tendency towards less swelling, which became significant after one week. As for many other NSAID, the reports regarding the effects of indomethacin on acute inflammatory reactions are conflicting. Some investigators 
have reported the drug to significantly reduce post-surgical oedema in rats (Amin et al. 1983) and humans (Penners 1971), while others have found no decrease in the posttraumatic swelling (e.g. Huskisson et al. 1973, Petersen 1975).

With regard to the effects of the two drugs on fracture and wound healing, it has been suggested on the basis of clinical observations in humans (Pfelfer 1967), as well as from experiments in animals (Lindner 1967), that oxyphenbutazone does not disturb the healing of bone injuries. Actually, oxyphenbutazone has been reported to accelerate repair of damaged muscular fibres (Morger 1967), and in contrast to indomethacin the drug has been found to increase the tensile strength of experimental wounds in animals (Zederfeldt \& Gruber 1967). So far, there seems to be only one report which suggests that human fracture repair is inhibited by indomethacin (Sudmann \& Hagen 1976), but there is also evidence from experimental models in rats that indomethacin may delay or inhibit fracture healing (Sudmann et al. 1979, Elves et al. 1982).

With the present methods of assessment, we were neither able to detect any beneficial effect of phenylbutazone on wound and bone healing, nor any deleterious effect of indomethacin on these processes. Our findings with regard to indomethacin agree with those of Allgöwer et al. (1963), who concluded that short-term treatment with indomethacin has no effect upon the healing of fractures. It might be that our period of drug administration was too short to reveal effects on bone healing, since it appears that the effect of indomethacin is short-lived and cessation of treatment soon after a fracture will allow normal healing to occur (Elves et al. 1982).

Difficulties were encountered in selecting an appropriate dosage of indomethacin. This drug gives a striking example of how differences in the pharmacokinetics of a drug may explain differences in drug response both within as well as between species. While the present mongrel dogs developed gastrointestinal lesions with a total dose of 4-7 mg indomethacin $/ \mathrm{kg}$ bwt, beagles have been reported to tolerate a single oral dose of 20 $\mathrm{mg} / \mathrm{kg}$ bwt without visible gastrointestinal lesions, and even a total dose of 100-200 $\mathrm{mg} / \mathrm{kg}$ bwt over a 5 to 10 day period was tolerated without excessive signs of toxicity (Tabata et al. 1984). Other workers have also found indomethacin to be more toxic in mongrel dogs than in beagles (Ruckebusch \& Toutain 1983). Beagles are known to metabolize drugs more rapidly than most other dogs (Frey at al. 1979), and this may explain why indomethacin is less ulcerogenic in beagles.

The much higher ulcerogenic potential of indomethacin in carnivores compared to many other species, is likely to depend on their predominantly biliary excretion and enterohepatic recirculation of the drug and thus prolonged exposure of these organs, while for example in humans the drug is eliminated mainly by the kidney. Duggan et al. (1975) found that the total accumulative amount of indomethacin excreted through the Ductus choledochus of the dog was $362 \%$ of the originally administered dose, while the corresponding value in man was only $10 \%$. In contrast to indomethacin, phenylbutazone has a half-life of only $6 \mathrm{~h}$ in dogs compared to $72 \mathrm{~h}$ in humans (Dayton et al. 1973). These pharmacokinetic differences may explain why, calculated as $\mathrm{mg} / \mathrm{kg}$ bwt/day, the ulcerogenic dose of indomethacin for dogs is only $1 / 8$ to $1 / 2$ of the therapeutic dose usually given to humans, while for phenylbutazone the ulcerogenic dose in dogs is 10 to 20 times the usual therapeutic dose in humans (Telemann 1983). 
Accordingly, when administering NSAID in veterinary practice, it is important to keep in mind the large variations in the pharmacokinetics. The utilization of doses recommended for one species, may result in unacceptable toxicity in some species or lack of effect in other species.

For dogs, indomethacin does not appear to be recommendable, while phenylbutazone presents a relatively wide margin of safety. The short half-life of phenylbutazone in dogs is, however, a disadvantage if it is intended to maintain relatively constant plasma concentrations, since the drug then has to be dosed 4 times daily (Kaergaard et al 1969).

The unwanted results of an excessive inflammatory reaction has long been recognized in surgery and traumatology (Peacock \& van Winkle 1976, Schiller \& De Silva 1979). It has been uncertain whether the results obtained with anti-inflammatory drugs in bilateral oral surgery would also apply to acute traumatic swellings in other parts of the body, e.g. of the extremities. The results obtained so far in the experimental model with bilateral orthopaedic surgery on the forelimbs of dogs, agree well with the results from human oral surgery. Phenylbutazone did not reduce the swelling significantly, and the reduction obtained with indomethacin was not impressive. In a similar placebo-controlled crossover study in dogs, a single preoperative injection of a glucocorticoid (betamethasone) reduced the swelling significantly. On the $3 \mathrm{rd}$ day the reduction was $43 \%$ (Mbugua et al. 1988). Significant reductions in the post-operative swelling were also recorded when paracetamol ( $0.5 \mathrm{~g} \times 3$ daily) and acetylsalicylic acid $(0.5 \mathrm{~g} \times 3$ daily) were tested against placebo in the model. On the $3 \mathrm{rd}$ post-operative day a reduction of $33 \%$ was observed with paracetamol and $24 \%$ with acetylsalicylic acid
(Mburu et al. 1988). Paracetamol has traditionally been said to be devoid of anti-inflammatory actıvity. At a dosage of $0.5 \mathrm{~g}$ three times daily, paracetamol was observed not only to result in marked reduction of the swelling, but also gave a very good analgesic effect. No adverse effects were observed.

Accordingly, neither phenylbutazone nor indomethacin seem to compete favorably with paracetamol in this model with an acute post-traumatic inflammatory reaction in the forelimbs of dogs.

This conclusion agrees with the results obtained in human oral surgery, according to which NSAID such as ibuprofen, oxyphenbutazone and acetylsalicylic acid (Løkken et al 1975, Album et al. 1977, Skjelbred 1984) are less efficient than paracetamol in curbing an acute post-traumatic inflammatory reaction (Løkken \& Skjelbred 1980, Skjelbred et al. 1984).

\section{Acknowledgements}

This study was supported by the Norwegian Agency for International Development (NORAD). The authors are grateful to $\mathrm{L}$. Sandvik (Ciba-Gergy Pharma A/S, Norway) for performing the statistical analyses and further for the valuable assistance offered by several staff members of the Department of Pharmacology and Toxicology, The Norwegian College of Veterınary Medicıne.

\section{References}

Album B, Olsen I, Løkken P Bilateral surgical removal of impacted mandibular molar teeth as a model for drug evaluation: A test with oxyphenbutazone (Tanderil). Int. J. Oral Surg. 1977, 6, 177-189.

Allgower M, Burrl C, Graffenried P, Guber UF, Heim U, Meng J, Segmueller G, Siegrist J, Studer $E$ Quantitative analysis of the effect of ant1-phlogistic substances in lower leg fractures. Schweiz. Med. Wochenschr. 1963, 93, 565-567.

Amin MM, Engel BM, Laskın DM: Effect of indomethacin on postsurgical edema in rats. Oral Surg. 1983, 55, 244-246. 
Dayton PG, Israll ZH, Perel JM. Influence of binding on drug metabolism and distribution. Ann. NY. Acad. Sci. 1973, 226, 172-194.

Duggan DE, Hooke KF, Noll RM, Chiu Kwan $K \cdot$ Enterohepatic circulation of indomethacin and its role in intestinal irritation. Biochem. Pharmacol. 1975, 24, 1749-1754.

Elves MV, Bayley I, Roylance PJ. The effect of indomethacin upon experimental fractures in the rat. Acta orthop. scand. 1982, 53, 35-41.

Frey $\mathrm{H}-\mathrm{H}$, Gobel $\mathrm{W}$, Löscher $W$ : Pharmacokinetics of primidone and its active metabolites in the dog. Arch. Int. Pharmacodyn. Therap. 1979, 242, 14-39.

Goldie IF, Gunterberg B, Jacobson C. Foot volumetry as an objective test of the effect of antiphlogistic drugs in ankle sprains. Rheumatol. Rehabil. 1974, 13, 204-207.

Higgins $A J \cdot$ The biology, pathophysiology and control of eicosanoids in inflammation. $J$. vet. Pharmacol. Therap. 1985, 8, 1-18.

Huskisson EC, Berry H, Street FG, Medhurst $H E$ Indomethacin for soft-tissue injuries. A double-blınd study in football players. Rheumatol. Rehabil. 1973, 12, 159-160.

Kaergaard NC, Stergaard EH, Frey $\mathrm{H}-\mathrm{H}$. Versuche zur Dosierung von Phenylbutazon beim Hund. (Dose experiments with phenylbutazone in the dog). Deutsch. Tierärtzl. Wochensebr. 1969, 76, 378-381.

Lees P, Higgins AJ Clinical pharmacology and therapeutic uses of non-sterordal anti-inflammatory drugs in the horse. Equine vet. J. 1985, 17, 83-96.

Lehman EL, d'Abrera HJM Non-parametrics: Statistical methods based on ranks. HoldenDay, San Fransisco 1975, pp. 18-23.

Lindner $J \cdot$ Diskussion (Discussion). In: Lindner, J. \& E. Wilhelm (eds.) Die post-traumatische Entzündung. (The post-traumatic inflammation). Hans Huber, Bern-Stuttgart 1967, p. 221.

Løkken P, Olsen I, Bruaset I, Norman-Pedersen $K \cdot$ Bilateral surgical removal of impacted lower third molar teeth as a model for drug evaluation: A test with ibuprofen. Eur. J. clin. Pharmacol. 1975, 8, 209-216.

Løkken $P$, Skjelbred $P$. Analgesic and anti-in- flammatory effects of paracetamol evaluated by bilateral oral surgery. Br. J. clin. Pharma col. 1980, 10, 253S-260S.

Løkken P, Skjelbred P Aspirin or paracetamol? Lancet 1981, $l$, 1346-1347.

Mbugua SW, Skoglund LA, Skjelbred P, Lokken $P$. Effect of a glucocorticoid on the post-operative course following experimental orthopaedic surgery in dogs. Acta vet. scand. 1988, 29, 43-49.

Mburu DN, Mbugua SW, Skoglund LA, Løkken $P$ Effects of paracetamol and acetylsalicylic acid on the post-operative course after exper1mental orthopaedic surgery in dogs. J. vet. Pharmacol. Therap. 1988, 11, 163-171.

Morger $R$. Oxyphenbutazone in Kaninchen-Modellversuch beim Volkmann-Syndrom. (Rabbit-model experiments with oxyphenbutazone in the .Volkmann-syndrome). In: Lindner, J. \& E. Wilhelm (eds.) Die posttraumatische Entzündung. (The post-traumatıc inflammation). Hans Huber, Bern-Stuttgart 1967, pp. 45-50.

Olesen E, Zachariae $L$ Absent effect of oxyphenbutazone (Tanderil) upon oedema following operation for Dupuytren's contracture. Acta chir. scand. 1965, 129, 352-358.

Peacock EE Jr, van Winkle $J r W$. Wound repair. W. B. Saunders 1976, pp. 185-190.

Penners $R$ Die Wirkung von Indomethacin auf das postoperative Ödem und die Wundheilung. (The effect of indomethacin on the post-operative oedema and wound healing). Arzneim.-Forsch. 1971, 21, 1842-1843.

Petersen JK. Anti-inflammatory and analgesic effects of indomethacin following removal of impacted mandibular third molars. Int. J. Oral Surg. 1975, 4, 267-276.

Pfelfer $H$ Klinische Beobachtungen über Knochenwundheilung unter Oxyphenbutazon. (Clinical observations of osseous wound healing with oxyphenbutazone). In: Lindner, J. \& E. Wilhelm: (eds.) Die posttraumatische Entzündung. (The post-traumatic inflammation). Hans Huber, Bern-Stuttgart, 1967, pp. 213-220.

Ruckebusch $Y$, Toutain $P L \cdot$ Non-steroidal antiinflammatory agents: Species differences in pharmacodynamics. Vet. Res. Com. 1983, 7, 359-368. 
Schiller R, De Silva JA Post-operative steroid injection: The first seventy-two hours of bone healıng. J. Amer. Podiat. Assoc. 1979, 69, 364-366.

Skjelbred $P$ The effects of acetylsalıcylic acid on swelling, pain and other events after oral surgery. Brit. J. clin. Pharmacol. 1984, 17, 379-384.

Skjelbred P, Lokken P Post-operative pain and inflammatory reaction reduced by injection of a corticosteroid. A controlled test in bilateral oral surgery. Eur. J. clın. Pharmacol. 1982a, 21, 391-396.

Skjelbred $P$, Løkken $P$. Reduction of pain and swelling by a corticosteroid injection 3 hours after surgery. Eur. J. clin. Pharmacol. 1982b, 23, 141-146.

Skjelbred P, Løkken P, Skoglund LA Post-operative administration of acetaminophen to reduce swelling and other inflammatory events. Curr. Ther. Res. 1984, 35, 377-385.

Sudmann E, Dregelid E, Bessesen A, Morland J Inhibition of fracture healıng by indomethacin in rats. Eur. J. clin. Invest. 1979, 9, 333339.

Sudmann E, Hagen $T$ Indomethacin-induced delayed fracture healing. Arch. Orthop. Unfallchir. 1976, 85, 151-154.

Tabata K, Ohtsukı H, Okabe $S$ Role of lymphoid nodules in pathogenesis of indomethacin-induced gastric lesions in dogs. Dig. Dis. Sci. 1984, 29, 346-352.

Teelmann $K$ Die Magen-Darm-Empfindlichkeit des Hundes gegenüber nichtsteroidalen Ant1phlogistıka/Antırheumatıka. (Gastro-ıntestinal sensitivity for non-steroıdal antiphlogistics/antirheumatics in the dog). Kleıntierpraxis 1983, 28, 177-188.

Vinegar $R$, Truax $J F$ Pathways to inflammation II. Introduction to and philosophy of the symposium. Fed. Proc. 1982, 41, 2567-2568.
Zederfeldt B, Gruber UF Der Einfluss von Indomethacin auf Wundheilung. (The effect of indomethacin on wound healing). In: Lindner, J. \& E. Wilhelm (eds.) Die posttraumatische Entzündung. (The post-traumatic inflammation). Hans Huber, Bern-Stuttgart 1967, pp. 51-55.

\section{Sammendrag}

Effekt av fenylbutazon og indomethacin på det post-operative forlop etter eksperimentell ortopedisk kirurgı på hunder

Randomiserte placebo-kontrollerte overkryssningsstudier ble utført på hunder. To non-steroide ant1-inflammatoriske legemidlers (NSAID) evne til å påvirke det akutte inflammatoriske postoperative forløp ble undersøkt. To "identiske" kırurgıske inngrep ble utført på forlabbene på hvert dyr med 28 dagers mellomrom slik at en parvis sammenligning av klıniske post-operative inflammasjonssymptomer og tllheling kunne utføres. I en studie ble $300 \mathrm{mg}$ fenylbutazon gitt 2 ganger daglig i 8 dager og sammenlignet med placebo. I en annen studie ble $5 \mathrm{mg}$ indomethacin gitt 2 ganger daglıg i 8 dager og sammenlignet med placebo. Fenylbutazon reduserte ikke den postoperative hevelse, men reduserte smerte og haltıng. Indomethacın viste en tendens til å redusere den post-operatıve hevelse, men reduserte ikke smerte eller halting. Ingen av de undersøkte NSAID syntes å påvirke den klinıske sår- eller frakturhelıngen. Det var vanskelig å velge en opt1mal klınısk dosering av indomethacın pga stor evne tıl å fremkalle gastrointestinale ulcerasjoner og blødninger på hundene. I denne eksperimentelle kirurgiske modellen med akutt inflammasjon viste hverken fenylbutazon eller indomethacin noen betydelig ant1-inflammatoriske eller analget1ske egenskaper. Paracetamol har tidlıgere 1 den samme modellen vist seg å redusere post-operatıv hevelse og smerte uten noen t1lsynelatende bivirknınger. Paracetamol synes å være et bedre alternativ enn fenylbutazon og indomethacin til å redusere akutt post-operatıv hevelse og smerte.

(Recelved February 1, 1988, accepted June 6, 1988)

Reprints may be requested from: S. W. Mbugua, Department of Clinical Studies, University of Nairobi, P. O. Box 29053 Kabete, Nairobi, Kenya. 
